\title{
THE SPREAD OF ENGLISH IN CHINA AND ITS IMPLICATIONS
}

Wang Lidi, Beijing Foreign Studies University

Correspondence to Wang Lidi:wanglidi@yahoo.com

The rise of English as a predominant foreign language in China in the past three decades driven by the force of globalisation coincided with China's efforts to open up herself to the rest of the world. It is estimated that the number of learners of English in China exceeds 300 million, which takes up about a quarter of the country's 1.3 billion people (Dai, 2007). At the turn of the century, the Ministry of Education implemented a scheme that required English be taught in year three and, in some cases, in year one at all primary schools up through secondary and tertiary education. Well-off parents in big cities send their pre-school children to bilingual or English-speaking kindergartens with the hope that this will give their children added strength in facing future competition. As a result, more people have acquired English as a foreign language to varying degrees of competence, which facilitates their functioning in a globalised context. Nevertheless, the benefits gleaned from using English as a foreign language also come at a price, to the detriment of the learning and use of other foreign languages. French, German, Russian, Japanese and other foreign languages used to be taught in many secondary schools in the past; today they are almost non-existent at that level with the exception of a few schools specialising in foreign language teaching.

There are plenty of reasons why people in China want to invest their time and efforts in learning English (Gai, 2004). As an international language, English empowers individuals with the skills that are absolutely essential in the pursuit of college education at home, education opportunities abroad, career development and job promotion. Besides, speaking English projects a very positive image to the public as being well-groomed, informed, open-minded and pro-West. Even state leaders of the country try to woo their foreign counterparts by breaking into English sometimes when they meet on public occasions. Increasingly, there are needs arising from more practical considerations as well, with China becoming irreversibly more interwoven into the world market, for instance, communicating with people from other countries at work, operating their own business globally, or simply updating themselves on current affairs through the Internet and other channels of the media in this age of information explosion.

Clyne and Sharifian cite Kachru's (1986) conceptualisation of the English-speaking countries in the form of three concentric circles. The notion can be extended and adapted 
to describe the situation concerning the use of English and other foreign languages in China as well, with the "Inner Circle" (IC) referring to situations where only Chinese is used for communication among those who speak the language; the "Outer Circle" (OC) to situations where China is dealing with other non-English speaking countries on a bilateral basis and where the language of that country is used; and the "Expanding Circle" (EC) to situations where English is used in dealing with people who are native speakers of English or who speak English as their second or foreign language. In the latter case, English serves as a lingua franca among non-native speakers of English.

China remains basically a Chinese-speaking society: that is to say that when they are interacting among themselves, Chinese is used to the exclusion of English and other foreign languages. ${ }^{1}$ The IC of the proposed Three-Circle analogy reflects this reality. OC depicts the use of foreign languages in China other than English. As a language policy, China encourages the use of native languages when interacting bilaterally with people from different countries. Some of these languages, such as French, German, Spanish, Russian, Japanese and Arabic, are taught in specialised foreign language schools at the secondary level. At the tertiary level, undergraduate and postgraduate programmes are offered in some fifty different foreign languages. The $29^{\text {th }}$ Olympic Games held in Beijing in August of 2008 recruited volunteers who were able to speak 48 foreign languages altogether, which is unprecedented in Olympic history. The spread of English has not only allowed Chinese users of English to gain access to the English-speaking world, which is often thought of as representing the industrialised West, but also facilitates communication and interactions with those who speak English as a second or a foreign language in other countries. However, this dominant position has had the effect of further marginalising the learning and use of other foreign languages in China.

As an international language, English has greatly eased the problem of communication across different cultures and has had an enormous impact on the Chinese in their socioeconomic development and their way of life in general as it is influenced by the industrialised countries. Chinese users of English normally regard British English and, increasingly, American English as representing the standard way of talking and writing in English. For them, it is a question of how to approximate to standard English rather than to deviate from such norms in order to flaunt their own variety of English, which is often derided as Chinglish. The exception comes when authoritative texts have to be translated into English. The translator then has to choose between bowing to the authority and pleasing the target language audience, often resulting in laboured word-for-word translation of such texts in English. Other than that, few people would accept a Chinese 
variety of English as being appropriate. Chinese learners and users of English are less burdened with the problem of cultural identity, which is often part and parcel of Englishspeaking, precisely because of its status as a foreign language for the Chinese.

English encounters problems in China typical of a foreign language. Despite much enthusiasm of the learners of English in the country, the general level of achievement is limited. This has partly to do with the fact that English is used as a foreign language, and partly the limited resources available to the learners in formal and informal education. It is true that China is closer to the rest of world more than ever with increased interactions with people from all over the world, but much of this cross-cultural communication is still mediated through translation and interpretation, as witnessed by the chronic shortage of qualified translators and interpreters and subsequently the mushrooming of translator and interpreter training programmes in tertiary and post-tertiary education in recent years. Western media and publications have yet to find a way to be available to English learners and the public in general, due to economic and sometimes ideological constraints. For youngsters at school, English largely means classroom teaching/learning and for the sake of passing examinations. They seldom have exposure to using English outside their classrooms and therefore feeling a genuine need for communicating in English. They are taught in large numbers in crammed classrooms by teachers who are often professionally less competent than desired. Those who can afford to study and stay in an English-speaking country will remain small in number as compared with the large numbers of English learners in primary and secondary school and in universities. Further efforts should be made to allocate more educational resources to the teaching and learning of English and to other foreign languages as well in China.

Clyne and Sharifian also note that Graddol (2006) reports Mandarin Chinese and Spanish are challenging English in terms of their proliferation in the world. Indeed, it was reported in 2004 by the Xinhua News Agency that the number of overseas students studying Chinese in universities in Mainland China reached 110,844, representing a 43 per cent increase compared with the previous year, and the students came from 178 different countries. That same year, the Chinese government launched a Chinese learning campaign by setting up Confucius Institutes in foreign universities. A total number of 277 Confucius Institutes have been set up in 77 countries as of 2008. It is estimated that there are currently over 30 million learners of Chinese overseas and the number is expected to reach 100 million by the year 2010. Nevertheless, Chinese cannot constitute any serious challenge to this dominating position of English as an international language, either in terms of the sheer numbers of learners of these languages or the functions they play in cross-cultural communication. On the latter point, Chinese is basically used among 
Chinese speakers, or at least one party participating in the communicative event is a native speaker of Chinese. One can hardly find situations where Chinese serves as a lingua franca among non-native speakers of Chinese, as does English. Whether Chinese will become an international language in the future remains an open question.

To sum up our observations on the development of English used as a foreign language in China, English has facilitated the country's effort to modernise by providing an effective means of communication with the rest of the world for understanding and trust. English has substituted other foreign languages in many instances of cross-cultural communication, and therefore, further marginalised the learning of these foreign languages in China, which is regrettable. The growing number of people learning to use Chinese should be seen as a welcome sign of the emergence of a multipolar world and need not be a cause for alarm that challenges the dominating position of English as an international language.

\section{ENDNOTES}

Ethnic minorities in China, such as Tibetans, Mongolians and Uygurs have their own languages, which enjoy equal status with Mandarin Chinese.

\section{REFERENCES}

Dai, Weidong. (2007). Opportunities and challenges of foreign language teaching. Shanghai: Foreign Language Teaching Press.

Gai, Yihong. (2004). Socio-psychology of English learning by Chinese university students. Beijing: Foreign Language Teaching and Research Press.

Graddol, D. (2006). English next. London: British Council.

Kachru, Braj B. (1986). The power and politics of English. World Englishes, 5 (2/3), 121-140.

Cite this article as: Wang, Lidi. 2008. 'The spread of English in China and its implications'. Australian Review of Applied Linguistics, International Forum on English as an International Language, special forum issue edited by Sharifian, Farzad; Clyne, Michael. 31 (3): pp. 32.1-32.4. DOI: 10.2104/aral0832. 